\title{
THE COMPETITIVENESS OF PODKARPACKIE REGION IN POLAND: A COMPARATIVE ANALYSIS WITH RESPECT TO CHOSEN BENCHMARKS
}

\begin{abstract}
Regional competitiveness is a phenomenon that is permanently inscribed in the process of managing the socioeconomic development of regions. Institutions of public administration at every level must take into account this aspect when planning strategic policy interventions. This article focuses on the regional dimension, which is essential for cohesion and development policies within the European Union. Effective management of growth, however, requires an appropriate definition of the concept of competitiveness, as well as measuring its condition. This article is an attempt to do this for one region in Eastern Poland: Podkarpackie.

Currently, Podkarpackie is the only region of Eastern Poland that have built a development policy on the basis of innovation. At the same time, the region has many historically conditioned structural problems that hinder its development. It is also strongly determined by the interaction with sub-regional growth centers such as Krakow and Warsaw. Therefore, it is an interesting region to study competitiveness.

In order to measure the competitive position we used the model of competitiveness developed by J. Strojny ${ }^{4}$. For its construction the AHP method was used. Then, on the basis of collected statistical variables, a comparative analysis between Podkarpackie and other regions was carried out. Both the zero-unitarisation method and single-based indices were applied.
\end{abstract}

Keywords: region, regional competitiveness, comparative analysis, AHP

\section{INTRODUCTION}

Competition and the competitiveness of regions is a very widely studied issue in the social sciences, especially in economics and management. The globalizing economy creates new background for all types of organisations to function in. The role of those institutions managing the development of territorial units, including the broadly defined public administration, has also changed. Nowadays, they are responsible for undertaking such

\footnotetext{
${ }^{1} \mathrm{PhD}$ J. Strojny, Department of Economics, University of Technology, Rzeszow, Av. Powstańców Warszawy 12, e-mail: jstrojny@prz.edu.pl (corresponding author)

${ }^{2}$ Prof. W. Heijman, PhD, Dept of Social Sciences, Wageningen University, Hollandseweg 1, 6706 KN Wageningen, The Netherlands, e-mail: wim.heijman@wur.nl

${ }^{3} \mathrm{PhD}$ P. Stefanów, Statistics and Demography, A.F. Modrzewski Krakow University, Str. Gustawa HerlingaGrudzińskiego 1, e-mail: pstefanow@afm.edu.pl

${ }^{4}$ The Region's Competitiveness Model was presented for the first time during the International Scientific conference "Economics and Management, ICEM" 2015 in the paper titled: Implementation of the AHP and benchmarking in Strategic Analysis of Polish Regions.
} 
actions that will be sustainable in the long-term development of economic systems. In the case of Poland, the following dimensions of such management can be distinguished: (1) international (European Union), (2) national, (3) regional ${ }^{5}$, (4) local (districts ${ }^{6}$ and municipalities).

The terms of a development policy and its effectiveness at each of these levels of management depends largely on the competitive position of a territorial system. the question remains, of course, as to how to describe the level of competitiveness, as well as how to measure it. The answer to this question is so important that only those areas of the organization or its environment that are a subject to some degree of quantification can be managed. Researchers refer to this issue in various ways. Some focus on the mechanisms of capital flows, their efficiency and their effects on economic growth. Others define multidimensional endogenous potential models and prove their relationship with the wider development process. Still others point to the existence of certain commodity markets, where competing entities are localized in different areas (e.g. cities, regions, countries). Finally, there are concepts relating to two different phenomena, such as convergence and concentration of capital. The mentioned approaches can also be applied to the phenomenon of competition of territorial units.

This article attempts to define and measure competitive position by comparing a group of units in Poland on a regional level. The study was based on the example of one of the voivodships (regional level territory) in relation to the chosen other regions which were treated as benchmarks. In the analysis, we selected the following regions: Mazowieckie, Małopolskie, Lubelskie, Podlaskie and the Zachodniopomorskie. The first two regions were selected because they encompass strong growth centers (Warsaw in Mazowieckie, and Krakow in Małopolskie), which forcefully affect the studied region in many areas of competition. Like Podkarpackie, the other three regions are faced with important structural and developmental problems, hence their role as points of reference. The study posed the following research question: What are the trends in the competitive position of Podkarpackie compared to the selected regions (benchmarks)?

Responding to this question, the Region's Competitiveness Model (RCM) included three dimensions: (1) competitiveness with respect to the citizen, (2) competitiveness with respect to companies, and (3) competitiveness with respect to tourists. The general index of competitiveness along with the indices of competitiveness for each of mentioned dimensions were calculated. During the phase in which the model was created and the significance of its elements was measured, the AHP method was used. ${ }^{7}$ In essence this means that experts estimate the weights of the variables. In the comparative analysis phase, both the zero-unitarisation method and single-based indices are used. Thanks to the first tool, standardized variables to measure the competitive position on each level of the presented model were achieved. In turn, single-based indices were used in order to show the dynamics of changes in competitiveness level during the analyzed period.

\footnotetext{
${ }^{5}$ In Poland this level of territorial unit is called voivodship.

${ }^{6}$ In Poland this level of territorial unit is called poviat.

${ }^{7}$ Analytic Hierarchy Process.
} 


\section{COMPETITIVENESS OF THE REGIONS - LITERATURE REVIEW}

The concept of a 'region' is defined in many different ways in the literature. Isolating the region in economic terms should take into account that it "is an area delimited on the basis of the entire collection of interrelated economic phenomena" . It is therefore "a composite part of a larger economic and social space, which differs from other surrounding territories in economic, social, demographic, cultural, natural, and infrastructure systems connected by material and informational relations" $"$ The elements that make up the region "are linked with each other and with the natural environment by relationships of coexistence and interdependence, and with the external environment - by the relationship of interdependence with a high intensity" 10 . For the purposes of this study, the concept of the region understood as a voivodship was identified. This is the administrative unit in Poland separated at the regional level (NUTS2 ${ }^{11}$ ). In regional analyses in Poland the voivodship is mostly used as the territorial unit. ${ }^{12}$ It is therefore constituted as the "basic unit of structuring and organizing of the socioeconomic reality of the country"13.

The issue of regional competitiveness can be analyzed from the perspective of economic growth theory, of new economic geography and of course of contemporary theories of regional development. The concept of competition is often interpreted in the context of marketing, and therefore as the fight for customers on some kind of market ${ }^{14}$. Competition can be also identified with the characteristics of an entity (e.g. the region), determining its ability to compete ${ }^{15}$. The literature often mentions the properties of a competitive region, such as the ability to ${ }^{16}$ : (1) seize opportunities in an environment, (2) maintain a competitive advantage in terms of overall development processes, (3) build an environment which is conducive to innovation, (4) create a climate for entrepreneurship. The article assumes that the competitiveness of the region is synonymous with its ability to attract mobile capital and tourists to its territory and, upon this basis, to generate the processes of socioeconomic development and economic growth ${ }^{17}$.

The concepts aimed at clarifying both the competitiveness of the region and the factors affecting it fit mainly under the theory of regional development. To some extent, its foundations can be sought in new economic growth theory. Its basis is found in the models of

\footnotetext{
${ }^{8}$ A. Wróbel, Pojęcie regionu ekonomicznego a teoria geografii, PWN, Warszawa 1965, p. 19.

${ }^{9}$ V. Snieška, J. Bruneckienè, Measurement of Lithuanian regions by regional competitiveness index, Inzinerine Ekonomika-Engineering Economics 1/61 (2009), p. 46.

${ }^{10}$ R. Domański, Kształtowanie otwartych regionów ekonomicznych, PWE, Warszawa 1972, s. 7.

${ }^{11}$ NUTS - Nomenclature of Territorial Units for Statistics

12 Stownik podstawowych terminów samorządu terytorialnego, ed. M. Lisiński, Wyższa Szkoła Biznesu w Dąbrowie Górniczej, Dąbrowa Górnicza 2007, p. 101.

${ }^{13}$ T. Czyż, Zastosowanie modelu potencjału $w$ analizie zróżnicowania regionalnego Polski, "Studia Regionalne i Lokalne" 2002/2-3, p. 5.

${ }^{14}$ More: M.J. Stankiewicz, Konkurencyjność przedsiębiorstw. Budowanie konkurencyjności przedsiębiorstwa w warunkach globalizacji, Dom Organizatora TNOiK, Toruń 2002.

${ }^{15}$ More: M. Gorynia, B. Jankowska, Klastry a międzynarodowa konkurencyjność i internacjonalizacja przedsiębiorstwa, Warszawa, Difin 2008.

${ }^{16}$ More: M. Lisiński, op. cit.

${ }^{17}$ This concept of the regional competitiveness was presented for the first time by J. Strojny in the paper Implementation of the AHP and benchmarking in Strategic Analysis of Polish Regions during the International Scientific Conference "Economics and Management, ICEM 2015".
} 
economic growth presented by P.M. Romer ${ }^{18}$ and R.E. Lucas ${ }^{19}$, who assumed that the ability to generate production in a region stems from the possibility of accumulating capital (human and material), as well as from the technological potential installed there. Both here and in the other models, (e.g. S. Rebelo ${ }^{20}$, Ph. Aghion and P. Howitt ${ }^{21}$, or O. Galor i D.N. Weil ${ }^{22}$ ), it is assumed that the endogenous potential has an impact on the volume of production. The main questions in building the basis for the competitiveness are therefore: (1) how can internal resources be developed? and (2) how can internal resources be made more efficient in economic processes?

The key issue in relation to building the region's competitiveness then becomes to achieve a high capital accumulation. In regions that have reached such a state, the level of production and general development are at a high level. This is the basis of the polarization of regions and the formation of highly developed metropolitan systems around big cities. The ability to attract human and material capital makes them growth centers, strongly influencing the environment inside the region, or even beyond it. These phenomena are explained by a number of concepts, such as Growth Poles (F. Perroux ${ }^{23}$ ) or concepts by A.O. Hirschman ${ }^{24}$, J. Friedmann ${ }^{25}$, and M. Castells ${ }^{26}$. They point to the development of growth centers, which lead to increased disparities in terms of development between regions.

Of course, there is a capital flow between regions. This phenomena concerns both material and human capital. In the first case, there are observed processes of transferring the investment, whereas in the second case, a very significant process of migration can be identified. Flows from the less developed regions to the leading regions often relate to human capital. They cause the divergence phenomenon, and therefore a growing polarization between regions. Flows in the opposite direction are related to material capital (technology) and can therefore accelerate capital accumulation. Thanks to this, less developed regions may begin a path of faster economic growth, and therefore reduce the development gap between them and the leading regions. This phenomenon is known as convergence, thus reducing the variation between regions at the level of socioeconomic development $^{27}$.

Flows and capital accumulation positively affect the region's competitiveness in the markets of goods. Today, regional development theories are also very popular, these ex-

\footnotetext{
${ }^{18}$ More: P.M. Romer, The Origins of Endogenous Growth, "Journal of Economic Perspectives" 1994/8, p. 3-22.

${ }^{19}$ More: R.E. Lucas, On the Mechanics of Economic Development, "Journal of Monetary Economics" 1988/22, p. 3-42.

${ }^{20}$ More: S. Rabelo, Long-Run Policy Analysis and Long-Run Growth, "Journal of Political Economy" 1991/99, p. 500-521.

${ }^{21}$ More: Ph. Aghion, P.W. Howitt, The Endogenous Growth Theory, MIT Press, Cambridge 1998.

${ }^{22}$ More: O. Galor, D.N. Weil, Population, Technology and Growth, “American Economic Review” 90/4 (2000), p. 806-828.

${ }^{23}$ More: F. Perroux, Economic space: theory and applications, "The Quarterly Journal of Economics" 1950 , p. 89-104.

${ }^{24}$ More: A.O. Hirschman, The strategy of economic development, Yale University Press, New Haven 1958/58.

${ }^{25}$ More: J. Friedmann, The world city hypothesis, "Development and change" 17/1 (1986), p. 69-83.

${ }^{26}$ More: M. Castells, The Rise of Network Society, Blackwell Publishers, Oxford 1996.

${ }^{27}$ More: H. Linnemann, J.P. Pronk, J. Tinbergen, Convergence of economic systems in East and West, Netherlands Economic Institute, Rotterdam 1965; P. Wójcik, Dywergencja czy konwergencja: dynamika rozwoju polskich regionów, "Studia regionalne i lokalne" 32/2 (2008), p. 41-60.
} 
plaining the process of building a competitive advantage based on endogenous capacity to export (for more, see Staple Theory by H.A. Innis, D. Drache ${ }^{28}$ or New Trade Theory by Krugman $\left.{ }^{29}\right)$. From this perspective, the region's competitiveness is built on the efficiency and productivity potential of the enterprises located there. This perspective is presented in M.E. Porter's concept of the competitiveness of nations ${ }^{30}$.

Today, the possibilities to export in the broader context (building a competitive advantage in the region) mainly depend on the possibilities of accumulation of human capital and resource of knowledge as a consequence of it. This aspect is also taken into account in contemporary theories, referring both to learning mechanisms in the region (The Learning Region by R. Florida ${ }^{31}$ ), as well as its ability to develop a high specialization in some areas of competences (Smart Specialization) ${ }^{32}$. Nowadays a very popular in both, developed and emerging regions is the cluster concept. It creates a kind of entrepreneurial base for development and learning processes ${ }^{33}$. It is also an essential factor in determining the competitiveness of the region.

\section{MODEL OF THE COMPETITIVENES AND METHODOLOGY OF ITS INVESTIGATION}

The aim of the study is to identify the level of competitiveness of the Podkarpackie region of Eastern Poland compared to other selected Polish regions. The main research question is as follows: GRQ: What are the trends in the competitive position of Podkarpackie compared to the selected benchmark regions? To cover this question in further detail, a bundle of specific questions was prepared, as follows: DQ1)how can competitiveness be described and measured? DQ2)how is the competitiveness of Podkarpackie region shaped in terms of the factors that most adversely affect its competitive position? DQ3)how is the competitiveness of Podkarpackie shaped in relation to other regions with the systemic problems of development? DG4) which trends can be identified in terms of the competitiveness of Podkarpackie? Compared to other regions, is Podkarpackie improving, or losing, its competitive advantage?

The competitive model used in the study is an operationalization of the definition of competitiveness presented above (Figure 1). It was built in a hierarchical structure in which the competitiveness of the region $(C)$ is composed of three dimensions in relation to three separate groups of clients $\left(C_{i}\right)$ : (1) tourists $\left(C_{t}\right),(2)$ citizens $\left(C_{c}\right)$, and (3) business $\left(C_{b}\right)$. For each of these dimensions, four variables $\left(C_{i} n\right)$ were assigned, demonstrating the interest of individual customers in the specific region. In the construction of the model,

\footnotetext{
${ }^{28}$ More: H.A. Innis, D. Drache, Staples, markets, and cultural change: Selected essays, McGill-Queen's PressMQUP, Montreal 1995

${ }^{29}$ More: P. Krugman, Does the new trade theory require a new trade policy?, "The World Economy" 15/4 (1992), p. 423-442

${ }^{30}$ More: M.E. Porter, Konkurencyjna przewaga narodów, Polskie Wydawnictwo Ekonomiczne, Warszawa 1990.

${ }^{31}$ More: R. Florida, The Learning Region, [in:] Regional Innovation, Knowledge and Global Change, ed. Z.J. Acs, Pinter, New York 2000, p. 231-244.

${ }^{32} \mathrm{Ph}$. McCann, R. Ortega-Argilés, Smart specialization, regional growth and applications to European union cohesion policy, "Regional Studies" 2013, p. 1-12

${ }^{33}$ More: P. Dubini, The influence of motivations and environment on business start-ups: some hints for public policies, "Journal of Business Venturing" 1989/4, p.11-26.
} 
the method of AHP (Analytic Hierarchy Process) was used ${ }^{34}$. It has been created by T.L. Saaty in the 70 s of the last century ${ }^{35}$ and is used for multi-criteria preference analysis. During the study, in addition to construction of the model, this method was used to ascertain the weights of single elements of the model. Therefore, the weights of dimensions of competitiveness $\left(w_{i}\right)$ and the variables describing these dimensions $\left(w_{i} n\right)$ were identified, on the basis of assessments ${ }^{36}$ by comparing pairs of variables within each dimension of the competitiveness and then comparing between different dimensions of competitiveness. Saaty's nine-point scale was used to provide these comparisons ${ }^{37}$.

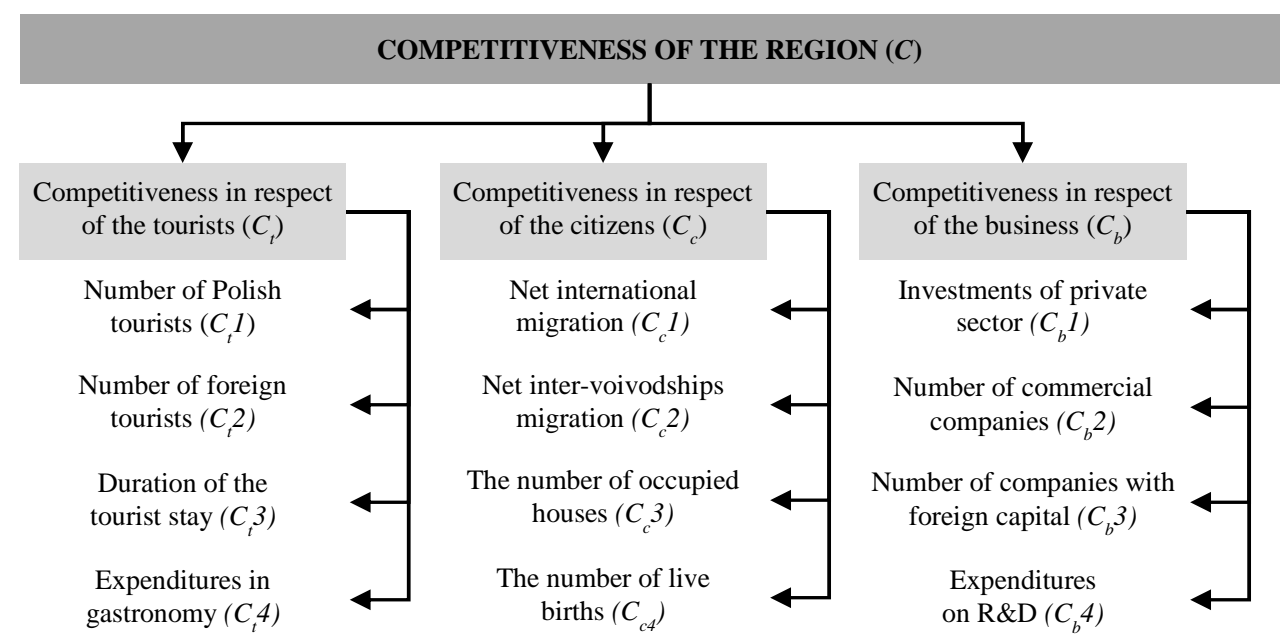

Figure 1. Region's Competitiveness Model (RCM) by J. Strojny.

Source: Own study.

In order to obtain measures of competitiveness, a mechanism of standardization and aggregation was used. In which the zero-unitarisation method was used to convert all variables to a form in which their value is in the range: $C_{i} n \in\langle 0.00 ; 1.00\rangle$. In subsequent years of the time series, the variables describing all Polish regions were compared. The best region in comparing group (in Poland) obtains the value of $C_{i} n=1$, and the worst $C_{i} n=0$. By converting variables into a comparable form, it was possible to construct indicators for dimensions of competitiveness (Formula 1) as well as the general index of competitiveness (Formula 2). The weighted means were used here, and the weight was calculated on the basis of judgements provided during AHP comparison analysis.

\footnotetext{
${ }^{34}$ More: A. Prusak, J. Strojny, P. Stefanów, Analityczny Proces Hierarchiczny (AHP) na skróty - kluczowe pojęcia i literatura, „Humanities and Social Sciences” 2014/4, p. 179-192.

${ }^{35}$ More: T.L. Saaty, How to make a decision: the analytic hierarchy process, "European Journal of Operational Research" 48/1 (1990), p. 9-26.

${ }^{36}$ Judgements were made by experts from Department of Economics in Faculty of Management in Rzeszow University of Technology.

${ }^{37}$ More: A. Prusak, P. Stefanów, AHP - analityczny proces hierarchiczny, CH Beck, Warszawa 2014.
} 


$$
\begin{gathered}
C_{i}=\sum_{i=1}^{n} C_{i} n \cdot w_{i} n \\
C=\sum_{i=1}^{n} C_{i} \cdot w_{i}
\end{gathered}
$$

Thus constructed, the set of measures, consisting of 16 standardized variables, three dimensional indicators of competitiveness and one general indicator of competitiveness, were subjected to further analysis. In this step, single-based indices $\left(S_{i}\right)$ were constructed, using 1999 as a base year (Formula 3). They allow the evaluation of changes of any meter indicator in an individual year with respect to the beginning of the researched period.

where:

$$
S_{i}=\frac{V_{i}}{V_{b}} \cdot 100 \%
$$

$S_{i} \quad$ - value of single-based index in $i$ year,

$V_{i} \quad$ - value of variable in $i$ year (e.g. $C_{i} n, C_{i}$ lub $C$ ),

$V_{b} \quad$ - value of variable in base year (in research: 1999).

Furthermore, the competitive gap values $\left(C G_{i} x / y\right)$ were analyzed. They were calculated as the difference between the values of the same measure in two different regions in a given year (Formula 4).

where:

$$
C G_{i} x / y=V_{i} x-V_{i} y
$$

$C G_{i} x / y$ - value of competitiveness gap in $i$ year for $x$ region regarding to the $y$ region,

$V_{i} x \quad$ - value of variable in $i$ year (e.g. $C_{i} n, C_{i}$ lub $C$ ) in $x$ region,

$V_{i} y \quad$ - value of variable in $i$ year (e.g. $C_{i} n, C_{i}$ lub $C$ ) in $y$ region.

The scheme of research described below was used to analyze the situation of Podkarpackie in comparison with the other selected Polish regions. As benchmarks, two groups of regions were selected - rapidly developing voivodships with large growth centers, and regions with structural development problems. The first group comprises Mazowieckie and Małopolskie, these being regions which directly threaten Podkarpackie on each of the analyzed markets. They strongly determine the competitiveness regarding to the citizens, as they attract young people. The second group consists of two regions of Eastern Poland, namely Lubelskie and Podlaskie. Like Podkarpackie, they lie on the eastern Polish border, and for a long period they also had comparable levels of competitiveness to that of Podkarpackie. Another peripheral region - Zachodniopomorskie - was also added to this group. For many years, this region has been struggling with development problems that hinder not only the increase, but even maintenance of the level of competitiveness.

\section{ANALYSIS OF THE COMPETITIVENESS OF PODKARPACKIE RE- GION WITH RESPECT TO CHOSEN BENCHMARKS}

Detailed results of the analysis of the competitiveness of Podkarpackie using the Regional Competitiveness Model are shown in Table 1. It comprises the values of the general indicator $(C)$, indicators counted for the individual dimensions of competitiveness $\left(C_{i}\right)$ and the variables that describe the dimensions $\left(C_{i} n\right)$. Table 1 also presents the so- 
called local weights, calculated on the basis of the AHP method for dimensions of competitiveness $\left(w_{i}\right)$ and variable $\left(w_{i} n\right)$.

Table 1. Results of the competitiveness analysis of Podkarpackie region in 2013.

\begin{tabular}{|c|c|c|c|c|c|c|c|}
\hline \multicolumn{8}{|c|}{ Indexes of competitiveness } \\
\hline \multicolumn{2}{|c|}{$C$} & $C_{t}$ & $w_{t}$ & $C_{c}$ & $w_{c}$ & $C_{b}$ & $w_{b}$ \\
\hline \multicolumn{2}{|c|}{0.33} & 0.15 & 0.16 & 0.48 & 0.28 & 0.31 & 0.56 \\
\hline \multicolumn{8}{|c|}{ Variables for $C_{t}$} \\
\hline$C_{t} 1$ & $w_{t} 1$ & $C_{t} 2$ & $w_{t} 2$ & $C \mathbf{t} 3$ & $w_{t} 3$ & $C_{t} 4$ & $w_{t} 4$ \\
\hline 0.20 & 0.13 & 0.06 & 0.28 & 0.33 & 0.30 & 0.03 & 0.29 \\
\hline \multicolumn{8}{|c|}{ Variables for $C_{c}$} \\
\hline$C_{c} 1$ & $w_{c} I$ & $C_{c} 2$ & $w_{c} 2$ & $C_{c} 3$ & $w_{c} 3$ & $C_{c} 4$ & $w_{c} 4$ \\
\hline 0.85 & 0.19 & 0.25 & 0.16 & 0.00 & 0.18 & 0.58 & 0.47 \\
\hline \multicolumn{8}{|c|}{ Variables for $C_{b}$} \\
\hline$C_{b} 1$ & $w_{b} 1$ & $C_{b} 2$ & $w_{b} 2$ & $C_{b} 3$ & $w_{b} 3$ & $C_{b} 4$ & $w_{b} 4$ \\
\hline 0.78 & 0.10 & 0.00 & 0.21 & 0.03 & 0.32 & 0.59 & 0.37 \\
\hline
\end{tabular}

Source: Own study.

The comparative analysis of the Podkarpackie region is presented in three steps: (1) analysis of competitive position, (2) analysis of the dynamics of change of competitive position, (3) competitive gap analysis. In each of these cases, the same time series was used, covering the period 1999-2013. Due to the limited length of the paper, the analysis was performed at the level of the general competitiveness index $(C)$.

Turning to the first of these dimensions of analysis, it should be noted that the value of the competitive position $(C)$ for Podkarpackie calculated for 2013 is 0.33 , which means that it is in 8th position among the ranking of competitiveness of all Polish regions. The most competitive is Mazowieckie voivodship $(C=0.94)$. This region has built up a large and constantly growing positive competitive gap in relation to all other regions in the country. It alone creates a separate category both in terms of the dynamics of development and growth processes, and in the area of competitive position.

Other regions in the ranking are at much lower levels. The competitive position of regions: Małopolskie, Pomorskie, Dolnośląskie and Wielkopolskie, values between $C \in\langle 0.40 ; 0.50)$. Podkarpackie belongs to a group of competitiveness within the range of values $C \square \square 0.30 ; 0.40$ ) which also includes Zachodniopomorskie, Ślaskie and Łódzkie. The other regions of Eastern Poland acquire a $C$ index value slightly above 0.20 (Lubelskie), or in the range to 0.2 (Podlaskie, Świętokrzyskie and Warmińsko-Mazurskie). Changes in the competitiveness index for Podkarpackie and the benchmarks included in this study are shown in Figure 2. 


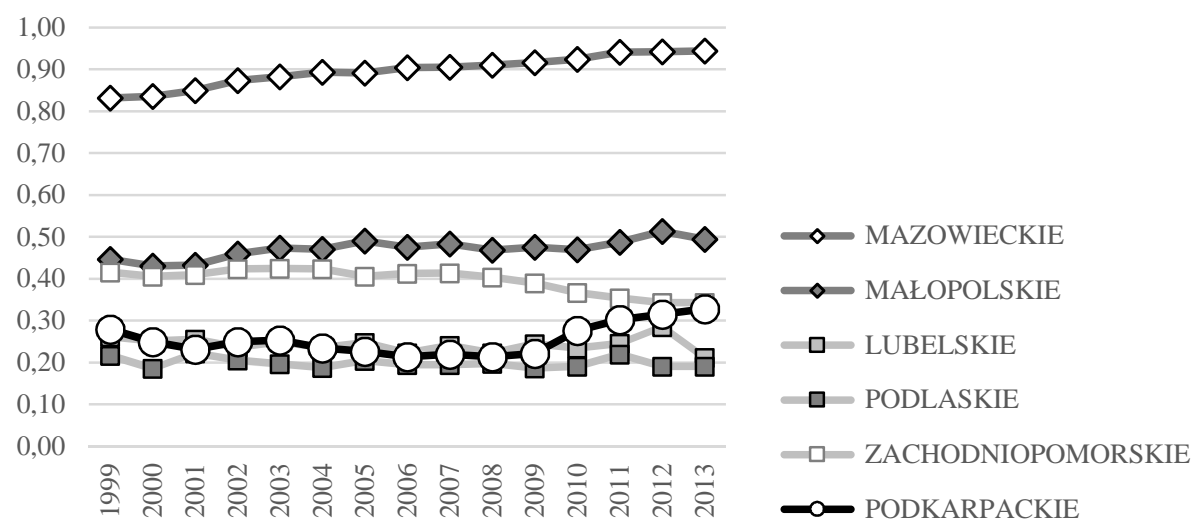

Figure 2. General competitiveness index $(C)$ - Podkarpackie in respect to the benchmarks (1999-2013).

Source: Own study based on GUS.

In order to clarify the current situation of Podkarpackie, one should refer to the dynamics of change of the indicator $C$, illustrated by single-based indices, with the base year 1999 (Figure 3). After Polish accession to the EU, Podkarpackie steadily lost its competitiveness. Then, from 2006-2009 there was a relative stabilization of the situation. The turning point was then the crisis period (2009-2013), when there was a significant increase in competitiveness compared to the other Polish regions, especially those with weaker fundamentals of development (e.g. other regions of Eastern Poland). Podkarpackie mainly owes it to the growing attractiveness in relation to companies. They increase their commitment in the region, intensifying R\&D activity. This is a good foundation for the further development of an analysed region. It is worth noting that during the researched period, the competitiveness of the voivodships Małopolskie and Mazowieckie systematically increased. In contrast, Zachodniopomorskie has systematically lost competitiveness since accession to the EU.

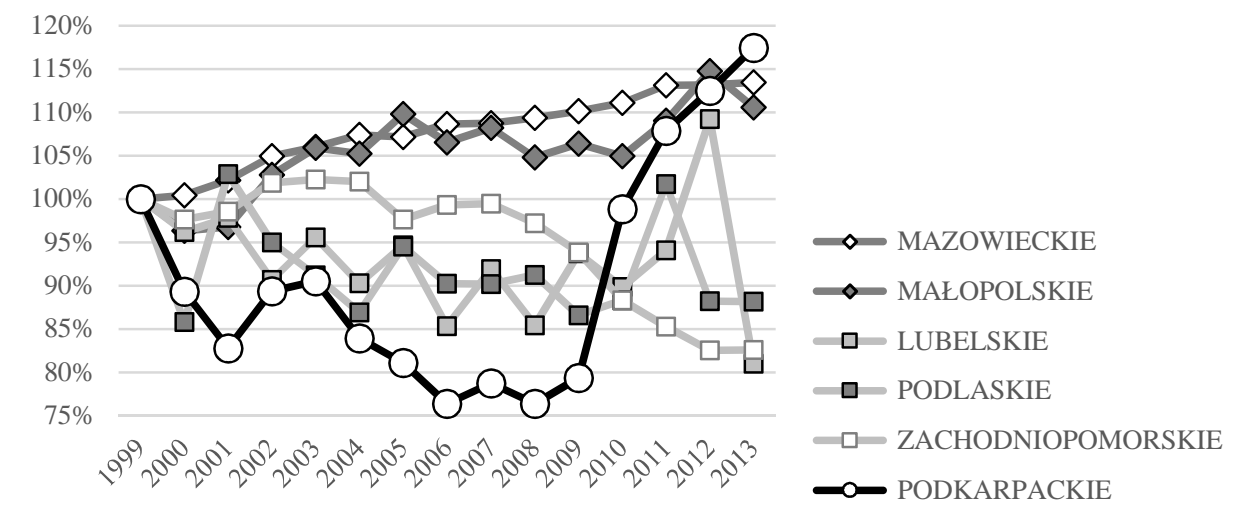

Figure 3. Changes of the general competitiveness index (C) regarding to base year 1999 r. - Podkarpackie with respect to the benchmarks.

Source: Own study based on GUS. 


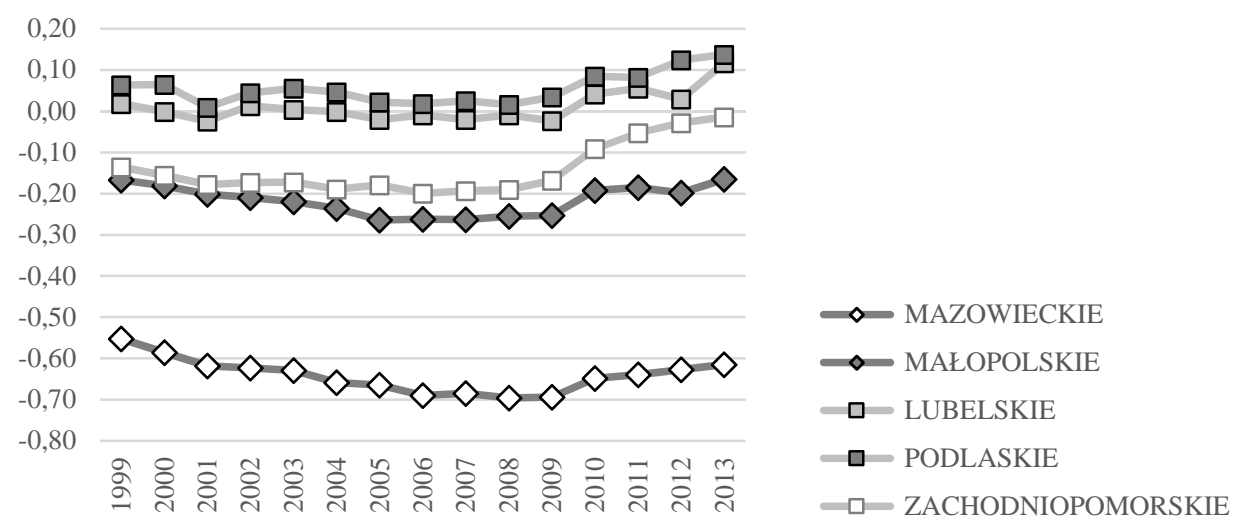

Figure 4. Competitive gap - Podkarpackie with respect to the benchmarks.

Source: Own study based on GUS.

Podkarpackie enjoys strong, positive dynamics which have a favorable effect on its competitiveness as compared to the benchmarks. Currently, in respect to the comparable regions of Eastern Poland (Lubelskie and Podlaskie), this competitive gap amounts up to approx. 0.10. The competitive gap between Podkarpackie and Zachodniopomorskie was also decreased, although in 1999, it was up to -0.14, and in 2006 it was at a level of -0.20 . Małopolskie region still maintains a significant competitive advantage over Podkarpackie. In 2013, the competitive gap was in fact -0.17 . In the last few years, however, it has been significantly reduced. In the years 2005-2009 it amounted to as much as -0.25 . Since 2009, Podkarpackie has also regularly caught up on the competitive gap with respect to Mazowiecki. Currently it amounts to -0.62 , while in 2009 it amounted to -0.69.

\section{CONCLUSIONS}

To conclude the presented research, it should be stated that in the field of phenomena covered by the Regional Model of Competitiveness, Podkarpackie has one of the largest dynamics of positive change in the country. In this respect, it stands out among other regions of Eastern Poland. The smart specialization strategy it has applied gives results primarily in the area of competitiveness relative to companies. Particularly noteworthy is the high activity of the private sector in terms of investment in R\&D. The foundations of this change are both historically conditioned traditions of the aviation industry and the current policy aimed at building a favorable environment for enterprises. The main structural problem is a drastically declining competitiveness in terms of its citizens, and above all, the threat of migration to large cities like Warsaw or Krakow.

It is hard to prejudge to what extent the currently observed, dynamic changes in competitiveness are likely to continue in the coming years. Certainly, Podkarpackie can be seen as a model for the other regions of Eastern Poland, or other less developed voivodships, such as Opolskie or even Zachodniopomorskie. Podkarpackie, by obtaining the previous high rate of growth in competitiveness, has a chance to achieve levels comparable with the Małopolskie within the next 10-15 years. However, it will require to meet two basic conditions: (1) a further increase in the investment attractiveness for enterprises and 
(2) stop the negative trends of competitiveness in relation to its citizens. For this purpose, it is necessary to further develop the function of the regional growth center of the city of Rzeszów, which is the capital of Podkarpackie region. Infrastructure projects which are currently implemented around the city allow the preparation of significant investment areas. Other projects generating business-friendly environment also create such an opportunity. Gradual improvements in the attractiveness of the regional labor market also represent a chance to increase the region's attractiveness to young people, thereby increasing human capital.

\section{REFERENCES}

[1] Aghion Ph., Howitt P.W., The Endogenous Growth Theory, MIT Press, Cambridge 1998.

[2] Castells M., The Rise of Network Society, Blackwell Publishers, Oxford 1996.

[3] Czyż T., Zastosowanie modelu potencjatu $w$ analizie zróżnicowania regionalnego Polski, "Studia Regionalne i Lokalne" 2002/2-3, s. 5.

[4] Domański R., Ksztattowanie otwartych regionów ekonomicznych, PWE, Warszawa 1972, s. 7.

[5] Dubini P., The influence of motivations and environment on business start-ups: some hints for public policies, "Journal of Business Venturing" 1989/4, p. 11-26.

[6] Florida R., The Learning Region, [in:] Regional Innovation, Knowledge and Global Change, ed. Z.J. Acs, Pinter, New York 2000, p. 231-244.

[7] Friedmann J., The world city hypothesis, "Development and Change" 17/1 (1986), p. 69-83.

[8] Galor O., Weil D.N., Population, Technology and Growth, "American Economic Review" 90/4 (2000), p. 806-828.

[9] Gorynia M., Jankowska B., Klastry a międzynarodowa konkurencyjność i internacjonalizacja przedsiębiorstwa, Difin, Warszawa 2008.

[10] Hirschman A.O., The strategy of economic development, Yale University Press, New Haven $1958 / 58$.

[11] Innis H.A., Drache D., Staples, markets, and cultural change: Selected essays, McGillQueen's Press-MQUP, Montreal 1995.

[12] Krugman P., Does the new trade theory require a new trade policy?, "The World Economy" 15/4 (1992), p. 423-442.

[13] Linnemann H., Pronk J.P., Tinbergen J., Convergence of economic systems in East and West, Netherlands Economic Institute, Rotterdam 1965.

[14] Lucas R.E., On the Mechanics of Economic Development, "Journal of Monetary Economics" $1988 / 22$, p. 3-42.

[15] McCann Ph, Ortega-Argilés R., Smart specialization, regional growth and applications to European union cohesion policy, "Regional Studies", 2013, p. 1-12.

[16] Perroux F., Economic space: theory and applications, "The Quarterly Journal of Economics" 1950, p. 89-104.

[17] Porter M.E., Konkurencyjna przewaga narodów, Polskie Wydawnictwo Ekonomiczne, Warszawa 1990.

[18] Prusak A., Strojny J., Stefanów P., Analityczny Proces Hierarchiczny (AHP) na skróty - kluczowe pojęcia i literatura, „Humanities and Social Sciences” 2014/4, p. 179-192.

[19] Prusak A., Stefanów P., AHP - analityczny proces hierarchiczny, CH Beck, Warszawa 2014.

[20] Rabelo S., Long-Run Policy Analysis and Long-Run Growth, "Journal of Political Economy" 1991/99, p. 500-521.

[21] Romer P.M., The Origins of Endogenous Growth, "Journal of Economic Perspectives" 1994/8, p. 3-22.

[22] Saaty T.L., How to make a decision: the analytic hierarchy process, "European Journal of Operational Research" 48/1 (1990), p. 9-26. 
[23] Stownik podstawowych terminów samorządu terytorialnego, ed. M. Lisiński, Wyższa Szkoła Biznesu w Dąbrowie Górniczej, Dąbrowa Górnicza 2007.

[24] Snieška V., Bruneckienė J., Measurement of Lithuanian regions by regional competitiveness index, "Inzinerine Ekonomika-Engineering Economics" 1/61 (2009), p. 45-57.

[25] Stankiewicz M.J., Konkurencyjność przedsiębiorstw. Budowanie konkurencyjności przedsiębiorstwa w warunkach globalizacji, Dom Organizatora TNOiK, Torun 2002.

[26] Strojny J., Implementation of the AHP and benchmarking in Strategic Analysis of Polish, International Scientific Conference "Economics and Management, ICEM 2015".

[27] Wójcik P., Dywergencja czy konwergencja: dynamika rozwoju polskich regionów, „Studia regionalne i lokalne" 32/2 (2008), p. 41-60.

[28] Wróbel A., Pojęcie regionu ekonomicznego a teoria geografii, PWN, Warszawa 1965.

\section{KONKURENCYJNOŚĆ PODKARPACIA - ANALIZA PORÓWNAWCZA WZGLEDEM WYBRANYCH BENCHMARKÓW}

Konkurencyjność regionów to zjawisko, które na stałe wpisało się w proces zarządzania rozwojem społeczno-gospodarczym systemów gospodarczych. Instytucje administracji publicznej na każdym poziomie muszą uwzględniać ten aspekt, kształtując politykę interwencji strategicznej. W niniejszym artykule skupiono się na wymiarze regionalnym, który jest podstawowy dla polityki spójności i rozwoju w Unii Europejskiej. Skuteczne zarządzanie rozwojem wymaga jednak odpowiedniego zdefiniowania konkurencyjności jako zjawiska, a co za tym idzie - także pomiaru jej stanu, luki konkurencyjnej oraz obserwowanych tendencji w tym zakresie. Niniejszy artykuł jest próbą przeprowadzenia całego procesu analizy konkurencyjności dla jednego z regionów Polski Wschodniej (województwo podkarpackie).

Celem artykułu jest identyfikacja pozycji konkurencyjnej badanego regionu oraz tendencji w tym zakresie w kontekście wybranych benchmarków, czyli regionów porównawczych. Podkarpackie jako jedyny region Polski Wschodniej zbudował aktualnie czytelną i opartą na innowacyjności politykę rozwoju. Oparł się przy tym na filozofii smart specialization, która jest kluczowa dla budowania pozycji konkurencyjnej. Jednocześnie region ten ma wiele historycznie uwarunkowanych problemów strukturalnych, które hamują jego rozwój. Jest także mocno determinowany przez oddziaływanie ponadregionalnych centrów wzrostu, takich jak Kraków i Warszawa. Dlatego też jest to ciekawy przykład badawczy w kontekście zagadnienia konkurencyjności.

W artykule wykorzystano model konkurencyjności autorstwa Jacka Strojnego w celu pomiaru pozycji konkurencyjnej. Do jego budowy wykorzystano metodę AHP. Następnie na podstawie zgromadzonych zmiennych statystycznych dokonano analizy porównawczej Podkarpacia względem wybranych regionów, wykorzystując metodę unitaryzacji zerowanej oraz indeksy jednopodstawowe.

Słowa kluczowe: region, konkurencyjność regionu, analiza porównawcza, AHP.

\section{DOI: 10.7862/rz.2015.mmr.13}

Tekst złożono w redakcji: marzec 2014

Przyjęto do druku: marzec 2014 